Volume 12 Number 4, October-December 2018: pp. 329-345. Copyright (c) 2018 FIAT JUSTISIA. Faculty of Law, Lampung University, Bandarlampung, Lampung, Indonesia. ISSN: 1978-5186 | e-ISSN: 2477-6238.

Fiat Justisia is licensed under a Creative Commons Attribution 4.0 International License, which permits unrestricted use, distribution, and reproduction in any medium, provided the original work is properly cited.

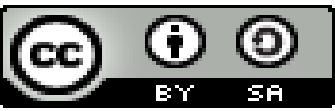

\title{
Criminal Violations of the Medical Ethics Code by Dr. Bimanesh
}

\author{
Naomi Jesica \\ University of Tarumanagara, Indonesia \\ naomihartanto@yahoo.com \\ Arlene Agustina \\ University of Tarumanagara, Indonesia \\ arlene68agustina@gmail.com \\ Klarika Permana \\ University of Tarumanagara, Indonesia \\ klarikapermana@gmail.com
}

\begin{abstract}
The relationship between doctors and patients is no longer seen as a mere relationship of trust, the relationship has been seen as a contractual relationship. The relationship between doctor and patient is an agreement known as a therapeutic transaction. Doctors as members of professions that devote their knowledge to the public interest, have freedom and independenceoriented to human values in accordance with the medical code of ethics. The medical code of ethics is regulated in the Indonesian Medical Ethics Code (KODEKI). The doctor's profession is required to work professionally and uphold the Code of Medical Ethics in carrying out his profession. However, there are some doctors who do not do their profession professionally. One of them, the case of Doctor Bimanesh Sutarjo allegedly cooperating to falsify Setya Novato's suspect to the hospital to be hospitalized with medical data that was allegedly manipulated in such a way as to avoid calls and checks by KPK investigators. Therefore, the authors are interested in writing this journal so that we understand better about the violations and law enforcement against KODEKI violations.
\end{abstract}


Keywords: Indonesian Medical Ethics Code (KODEKI), doctors, Doctor Bimanesh

How to Cite: Naomi Jesica, Arlene Agustina, and Klarika Permana, "Criminal Violations of the Medical Ethics Code by Dr. Bimanesh", Fiat Justisia, 12 (4), (2018).

DOI: https://doi.org/ 10.25041/fiatjustisia.v12no4.1378

\section{A. Introduction}

Today, the relationship between doctors and patients is no longer seen as a mere relationship of trust the relationship has been seen as a legal relationship or contractual relationship. The relationship between the patient and the doctor shifts in a balanced relationship because the patient and the doctor have their respective rights and obligations that must be fulfilled. The legal relationship that is established is a relationship to meet the goals of healing. According to the law, the relationship between doctor and patient is an agreement known as a therapeutic transaction

Transaction activity is an agreement so that the therapeutic transaction applies the engagement law, the doctor has the rights and obligations that govern and bind it. In its implementation in medical practice, there are also rights and obligations in the law that regulate and bind it. Various obligations both in the agreement and those regulated in the law, are the responsibilities that must be fulfilled according to the profession. ${ }^{1}$

Doctors as members of professions that devote their knowledge to the public interest, have freedom and independence-oriented to human values in accordance with the medical code of ethics. This medical code of ethics aims to prioritize the interests and safety of patients, ensuring that the medical profession must always be carried out with a noble intention and in the right way. ${ }^{2}$ The world of medicine (Medical Profession) is a specific profession, therefore it is directly related to the community or more specifically to human health. One consequence is that the medical profession gets much attention from the public. Events involving errors in serving patients can be brought to court.

The thing that needs to be studied is whether the prosecution of doctors or hospitals has a legal basis if viewed from the perspective of the Criminal Law,

\footnotetext{
${ }^{1}$ Anny Isfandyarie, Tanggung Jawab Hukum dan Sanksi bagi Dokter, Jakarta: Prestasi Pustaka, (2011), p.57.

${ }^{2}$ S. Soetrisno, Malpraktek Medik Dan Mediasi Sebagai Alternatif Penyelesaian Sengketa, Tangerang: Telaga Ilmu Indonesia, (2010), p.5.
} 
Civil Code, Medical Practice Law, and Indonesian Medical Ethics Code (KODEKI). ${ }^{3}$ The doctor in carrying out an action must be responsible as a legal subject for the rights and obligations. ${ }^{4}$ Actions or actions of doctors as legal subjects in society can be distinguished between actions that are not related to their profession and actions related to their profession as a doctor. The actions of doctors who have legal responsibility are those related to the implementation of their profession. ${ }^{5}$

In practice, the accountability of actions and actions of the medical profession as a legal subject can be viewed from two aspects, namely responsibility of the professional code of ethics. The medical code of ethics concerns two things that must be considered by medical profession developers, namely:

1. Medical ethics: the problem is related to the doctor's attitude towards his colleagues, his nurse, the community, and the government.

2. Ethics medical care: namely medical ethics in the form of guidelines in daily life, especially the attitude and actions of a doctor for patients who are their responsibility. Violations of the code of ethics do not cause formal sanctions against the perpetrators. For violators of the code of ethics, only corrective actions are taken in the form of reprimand and guidance. The hope is that similar violations will not happen again in the future. In other words, actions against violators of the code of ethics are only corrective and preventive.

Responsible Legal Answer is the legal responsibility of the doctor is a doctor's "attachment" to legal provisions in carrying out his profession. This attachment includes legal responsibility as follows:

1. Civil Liability: Initially, the responsibility of a doctor is limited to the contractual relationship between himself and the patient. Thus, the responsibility arising is limited to the scope of the field of civil law (for example, accountability arising from default or unlawful conduct). ${ }^{6}$ On this basis, the responsibility of the doctor only arises when a patient file a lawsuit against the doctor to pay compensation by an act that is detrimental to the patient. ${ }^{7}$ Performing defaults (Article 1239 of the Civil Code), conducting violations of the law (Article 1365 of the Civil Code), conducting negligence resulting in losses (Article 1366 of the Civil Code), Conducting work in charge (Article 1367 of the Civil

\footnotetext{
${ }^{3}$ Ninik Marianti, Malpraktik Kedokteran dari Segi Hukum Pidana dan Perdata, Jakarta: Bina Aksara, (1988), p.107.

${ }^{4}$ Anny Isfandyarie, Tanggungjawab Hukum dan Sanksi Bagi Dokter, Jakarta: Prestasi Pustaka, (2006), p.2.

${ }^{5}$ Ibid., pp.2-3.

${ }^{6}$ Sudikno Mertokusumo, Mengenal Hukum, Yogyakarta: Liberty, (2005), p.160.

${ }^{7}$ Ninik Marianti, Malpraktek Kedokteran, Jakarta: Bima Aksara, p.5.
} 
Code).$^{8}$ In this regard, the doctor can be sued civilly by the occurrence of a default, unlawful conduct, and negligence in carrying out his profession.

2. Criminal Liability: Criminal responsibility relating to professional errors, usually, is related to negligence issues, and the consent of the patient concerned. ${ }^{9}$ Professional errors in the form of negligence which requires criminal liability must be proven whether there has been a violation of informed consent or not. The term negligence in criminal law is identical to negligence.

3. Administrative Responsibilities: Administrative responsibility arises if a doctor or other health worker violates the applicable State administrative law, for example practicing a doctor without a license or permission, carrying out practice with a permit that has expired and practices without making medical records. The doctor's profession is required to work professionally and uphold the Code of Medical Ethics in carrying out his profession. However, some doctors do not do their profession professionally: one of them, the case of Doctor Bimanesh Sutarjo allegedly cooperating to falsify Setya Novato's suspect to the hospital to be hospitalized with medical data that was allegedly manipulated in such a way as to avoid calls and checks by KPK investigators. ${ }^{10}$

Seeing one of the cases that happened to the medical profession ethics carried out by Doctor Bimanesh Sutarjo The author was interested in discussing the topic in this journal with the title, "Dr. Bimanesh Judging from the Code of Medical Ethics", to find out the legal consequences of Doctor Bimanesh Sutarjo's actions against his actions. The problem will be discussed in this research is what the legal consequence of Doctor Bimanesh's actions that are proven to have violated professional ethics.

\section{B. Discussion}

Medical practice to run by the development of science and technology, the practice of medicine is regulated in law, namely the Law of the Republic of Indonesia Number 29 of 2004 concerning Medical Practices. The principle of medicine (State Gazette of the Republic of Indonesia of 2004 Number 116, from now on abbreviated as the Medical Practice Law) from the beginning to

\footnotetext{
${ }^{8}$ Safitri Hariyani, Sengketa Medik: Alternatif penyelesaian Perselisihan antara Dokter dengan Pasien, p.42.

${ }^{9}$ Nanik Marianti, Op. Cit., p.8.

${ }^{10}$ Ari Nursanti, Ini Kronologi Dugaan Persekongkolan Dokter dan Mantan Pengacara Setya Novanto, $\quad$ http://www.pikiran-rakyat.com/nasional/2018/01/10/ini-kronologi-dugaanpersekongkolan-dokter-dan-mantan-pengacara-setya-novanto, 29 Agustus 2018.
} 
the present is guided based on ethical principles namely nil nocere (not harm) and bonum facere (do good for the patients). The ethical principle is applied as a medical ethical norm, which has been used since the existence of people in the community who must treat sick people.

Professional work is a job that requires certain education and training, has a high position in the community, such as legal experts, journalists, lecturers, doctors, dentists, and pharmacists. Job profession is highly relied on professional ethics in providing services to the public. Professional ethics is a set of professional members' behavior about others. Ethical characteristics of the profession are as follows: ${ }^{11}$

1. Applies to the professional environment

2. Prepared by the relevant professional organization

3. Contain obligations and restrictions

4. Revitalizing human attitude

A medical profession has at least the following characteristics: ${ }^{12}$

1. The following education according to national standards, meaning that people included in the profession concerned must have completed the professional education. People who are doctors, by themselves must have passed the medical profession education (not just medical graduates).

2. The work is based on professional ethics. That is, in carrying out their duties or profession. A person must be based on or refer to professional ethics that has been formulated by his professional organization.

3. Prioritize the call of humanity rather than material benefits.

4. The work is legal (through licensing). To carry out duties or practices, this profession is required to legally license, or practice permits.

5. Its members learn lifelong. A member of the profession must always improve his profession through continuous learning.

6. Its members join a professional organization. A person who has passed a doctor's education must be a member of the IDI (Indonesian Doctors Association)

The similarities and differences between ethics and law are as follows: ${ }^{13}$

1. Ethical and legal equality

- Both are tools to regulate orderly social life

${ }^{11}$ M. Jusuf Hanafiah dan Amri Amir, Etika Kedokteran dan Hukum Kesehatan, Jakarta: Penerbit Buku Kedokteran EGC, (2007), p.2.

${ }^{12}$ Soekidjo Notoatmodjo, Metodologi Penelitian Kesehatan, Jakarta: Rineka Cipta, (2015), p.37.

${ }^{13}$ M. Jusuf Hanafiah, Op. Cit., pp.5-6. 
- As the object is human behavior

- Contains the rights and obligations of community members so as not to harm one another

- Awaken awareness to be human

- The source is the results of the thoughts of experts and the experience of senior members

2. Ethical and legal differences

- Ethics applies to the professional environment, the law applies to the public

- Ethics is prepared based on the agreement of members of the profession, the law is prepared by government agencies

- Ethics is not entirely written, the law is listed in detail in the book of laws and the state news sheet

- Sanctions against ethical violations in the form of guidance, sanctions against violations of law in the form of demands

- Violations of ethics are resolved by the Indonesian Medical Discipline Honorary Council (MKDKI) formed by the Indonesian Medical Council and/or by the Honorary Council of Medical Ethics (MKEK), which was formed by the Indonesian Doctors Association (IDI), violations of the law are settled by the Court.

- Completion of ethical violations is not always accompanied by physical evidence, settlement of violations of law requires physical evidence.

Ethics is a set of correct and good behaviors in a profession. Law is a law that is made by a power. Health law is a law that deals with health services for both providers and recipients of health services. ${ }^{14}$

The ethics of the medical profession is a set of behaviors of general practitioners and dentists about patients, families, communities, peers, and partners. ${ }^{15}$ Formulation of the behavior of the professional members compiled by professional organizations together with the government into a code of ethics for the profession concerned. ${ }^{16}$ Each type of health worker has a Code of Ethics, but the Code of Ethics for health personnel refers to the Indonesian Code of Medical Ethics (KODEKI). ${ }^{17}$

\footnotetext{
${ }^{14}$ Ibid.

${ }^{15}$ Soekidjo Notoatmodjo, Op. Cit., p.3.

${ }^{16}$ Ibid.

${ }^{17}$ Ibid.
} 
KODEKI as a moral guide for doctors in carrying out their profession consists of 4 (four) parts, namely: ${ }^{18}$ (1) General Obligations; (2) Obligations of Doctors to Patients; (3) Doctor's Obligations Against His Peers; and (4) The Obligations of Doctors Against Himself. The violation of medical ethics does not always mean a violation of the law, and vice versa, a violation of law, does not necessarily mean a violation of medical ethics. ${ }^{19}$ KODEKI violations are processed through MDKI or MKEK IDI, while legal violations are settled through a court. ${ }^{20}$ In health services, hospitals must also pay attention to the professional ethics of the workers who work in the hospital concerned. However, professionals who work in hospitals in giving decisions professionally are independent. The decision must be based on high awareness, responsibility, and morals by the ethics of each profession. ${ }^{21}$

To make it easier to understand, writers took Dr. Bimanesh case as an example. Bimanesh was found guilty of obstruction of justice after the court ruled that he co-conspired with lawyer Fredrich Yunadi to engineer a fake car crash so that former House Speaker Setya Novanto, who was Friedreich's client and a suspect in a major graft investigation, could elude Corruption Eradication Commission (KPK) investigators in November of last year.

The case started when dr. Bimanesh, who was named a co-conspirator in Fredrich's obstruction of justice case, backed up the lawyer's claims and tried to prevent KPK investigators from gaining custody of Novanto on medical grounds. However, the KPK was soon able to bring in their independent medical examiners who confirmed that Novanto had not suffered severe injuries, allowing investigators to take custody of the politician, move him to a new medical facility and have him arrested. Shortly after his client's arrest, Fredrich dropped out as Novato's legal counsel. But that didn't stop the KPK from arresting Fredrich in January on charges that he obstructed justice by trying to deceive investigators regarding Novato's health. During the trial, a litany of witnesses testified to Fredrich and dr. Bimanesh's duplicity is surrounding the case. One emergency room doctor said both Fredrich and dr hadand instructed him. Bimanesh to fake medical records showing Novanto had suffered severe injuries even before the politician had been brought to the hospital. In the end, it was Bimanesh, a kidney specialist, who ended up diagnosing Novato's car crash injuries (which obviously looked a little suspicious to investigators). The hospital's attending doctor at the time of the incident told the court that Fredrich had booked a VIP room at the hospital

\footnotetext{
${ }^{18}$ Chrisdiono M. Achadiat, Dinamika Etika dan Hukum Kedokteran Dalam Tantangan Zaman, Jakarta: Penerbit Buku Kedokteran EGC, (2004), p.147.

${ }^{19}$ M. Jusuf Hanafiah dan Amri Amir, Op. Cit.

20) Ibid.

${ }^{21}$ Juwita Suma, “Tanggung Jawab Hukum Dan Etika Kesehatan”, Jurnal Legalitas, 2 (3), (2009), p.90.
} 
before Setya's alleged accident. Two nurses testified to the fact that Novato's body was covered with a blanket when he entered the hospital, which was very unusual for car accident victims. They also told the court that Novanto did not appear to have any severe injuries on his face or head, contradicting Fredrich's "bakpao" claim. ${ }^{22}$

Judging from Doctor Bimanesh's case, there were several violations both regarding civil, criminal, and especially the Indonesian Medical Ethics Code.

\section{a. Criminal Liability}

Dr. Bimanesh's case which has been proven together with lawyer Fredrich Yunadi has been engineered so that Setya Novanto is treated at Medika Permata Hijau Hospital, it can be seen that Dr. Bimanesh has committed criminal offenses regarding the making of fake letters as stated in Article 267 paragraph 1 of the Criminal Code stated "A doctor who intentionally gives a false certificate about the presence or absence of a disease, weakness or disability is threatened with a maximum imprisonment of four years. Article 267 of the Criminal Code is certainly by the actions of Dr. Bimanesh against Setya Novanto. Dr. Bimanesh has made a doctor's statement that is not by the health condition of his patient, Setya Novanto. Therefore, it is appropriate for investigators to be investigated about the criminal act and legally processed with a 4-year prison sentence. In addition to Article 267, Dr. Bimanesh also violated Article 56 of the Criminal Code which was stated "Sentenced as someone who helped commit a crime:

1. Whoever deliberately helps commit the crime;

2. Whoever deliberately provides an opportunity, effort, or information to commit the crime."

So according to the case, Dr. Bimanesh gave the opportunity to Setya Novanto by giving false information about his health. Even though at that time Setya Novanto would be investigated by the KPK against e-KTP corruption cases.

\section{b. Ethical Violations}

If regarding ethical violations, Dr. Bimanesh violated Article 3 of the Indonesian Medical Ethics Code (KODEKI). Article 3 of KODEKI states that a doctor in performing his medical work, a doctor may not be influenced by something which results in the loss of freedom and independence of the profession. The scope of the article is:

22 http://www.thejakartapost.com/news/2018/07/16/setyas-doctor-jailed-for-obstruction-ofjustice.html 
1. Every doctor has the moral and responsibility to prevent the wishes of the patient or any party who intentionally or unintentionally intends to deviate or violate the law and/or ethics through medical practice/work. (15) Every doctor must support anti-corruption, collusion and nepotism programs from the government, professional organizations or any other party. Then if it is reviewed in Article 7 regarding the obligation of doctors to provide valid information and opinions and also from the scope of the article, states that: (1) In giving a medical certificate / expert or expert and expert opinion whatever the form and purpose, the doctor must base its contents on medical facts which he believes are true in accordance with the responsibility of his profession as a doctor.

2. A doctor's certificate and opinion/expert statement must be made with honesty, propriety, accuracy, and prudence based on the oath of office, by the provisions of the law and as far as possible free from conflicts of interest.

Dr. Bimanesh has also violated Article 3 of KODEKI, namely because he has chosen to, in doing his medical work, be influenced by something that results in the loss of freedom and independence of the profession. In order to counterfeit the letter, Dr.Bimanesh has also violated Article 7 of KODEKI because he has provided a medical certificate/expert or expert, and expert opinion of whatever form and purpose, does not base its contents on medical facts which he believes are true in accordance with the responsibility of his profession as a doctor and therefore the doctor's certificate and/or opinion/expert statement must be made not based on honesty, propriety, thoroughness, and prudence based on the oath of office, in accordance with the provisions of the legislation and as far as possible free from conflicts of interest.

\section{c. Civil Liability}

As explained above, violations of the code of ethics can also result in civil losses to patients and third parties related to the doctor's certificate, for example in the insurance sector. For the violation of the doctor, the party who feels aggrieved can file a lawsuit to the district court. Other legal consequences that can arise due to violations of the code of ethics, especially violations committed by Dr. Bimanesh are legal actions with third parties involving a doctor's statement to be null and void.

Parties who may file a lawsuit in the district court because they feel that they have been injured in a civil manner are patients on the basis of Article 1365 of the Civil Code (KUHPER) because the actions of Dr. Bimanesh have made the patient's legal actions with third parties null and void due to the agreement based on matters based on fraud (violating the legal requirements of the fourth hearing in Article 1320 KUHPER). If the falsification of a 
doctor's certificate made by Dr. Bimanesh was carried out by the willingness of his patient, Setya Novanto, so in this case, Setya Novanto could not have filed a lawsuit against Dr. Bimanesh.

But on the other hand, hospitals can sue doctors who cause harm to their patients. It is reflected in Article 46 of Law No. 44 of 2009 concerning the Hospital which regulates the responsibilities of the hospital, namely "The hospital is legally responsible for all losses incurred due to negligence committed by health workers in the hospital. This article is based on Article 1367 KUHPER where doctors who practice in hospitals are held as "people who are under the supervision of management and owners of the hospital. This assumption is true for doctors who work as hospital employees. Even so, doctors are not ordinary employees because doctors have professional autonomy that is beyond the control of the house. Not even all doctors who practice in hospitals are hospital employees. ${ }^{23}$

In addition to doctors who are hospital employees (often referred to as organic doctors, doctors remain, etc.), there are also doctors who are hospital partners, guest doctors, and consultant doctors. Even sometimes in a hospital, some doctors are volunteers. Hospital work partner doctors are doctors who treat their patients (generally hospitalized) in a hospital, but the doctor is not a hospital employee. In this case, the patient is a personal patient of the doctor who is hospitalized because he needs hospitalization or requires an action taken by the doctor himself in the hospital. This partner physician is legally equal to the hospital, independently responsible, proportionally by the provisions in the hospital, and bound by a work agreement with the hospital. Such a doctor will feel unfair if it is the hospital that must be held accountable for errors and omissions, as well as violations of the code of ethics that he has committed against patients and third parties who have been harmed due to a violation of the code of ethics. ${ }^{24}$

The relationship between hospitals, doctors, and patients is a triangular relationship that is connected. The relationship between patients and hospitals, the relationship between the hospital and the doctor, the relationship between the doctor and the patient. These three relationships are based on an engagement born of an agreement that is different from one another, depending on the parties in their relationship. In this case, if there is a professional error, the patient can determine the doctor based on errors and demands against the hospital based on the default that is added to the error.

\footnotetext{
${ }^{23}$ Haryanto Njoto, "Pertanggungjawaban Dokter dan Rumah Sakit Akibat Tindakan Medis yang Merugikan Dalam Perspektif UU No. 44 Tahun 2009 tentang Rumah Sakit". DiH Jurnal Ilmu Hukum, 7 (14), (2011), pp. 58 and 65.

${ }^{24}$ Ibid., p. 65.
} 
In the perspective of the relationship between the hospital and the doctor, the hospital where the doctor who violates the code of ethics can sue for the losses incurred because basically the loss/risk borne by the hospital is caused by the doctor. The claim is filed must pay attention to the relationship that underlies the relationship between the hospital and the doctor, as explained in the paragraph above, for example by looking at whether the doctor is a doctor as a hospital employee or a doctor as a partner. If the doctor is a hospital employee doctor, the hospital can file a lawsuit in court as mentioned above, but also the doctor is a partner, so the hospital cannot sue the doctor. Another option when in the dispute resolution process, the patient can also place a doctor who is negligent as a third party who must also bear the loss caused by negligence or the doctor itself.

As a result, in the case of Dr. Bimanesh, first of all, it is necessary to know whether the relationship that underlies the engagement between the hospital and Dr. Bimanesh himself, whether Dr. Bimanesh is a partner doctor or an employee doctor. Besides that, it is also necessary to pay attention to the contents of the agreement made between Dr. Bimanesh and the hospital where the doctor is practicing. Are ethical violations committed by doctor Bimanesh included in the category of default or unlawful act in the agreement if it turns out that the contents of the agreement state that a default or an illegal act, the hospital can sue Dr. Bimanesh for his actions in falsifying the doctor's certificate.

In the beginning, it was explained that in addition to being sued to court, violations of the code of ethics could also result in legal relations between patients and third parties related to the medical letter. One-third party that can be associated with the problem of Dr. Bimanesh is the insurance. If Setya Novanto enters into an insurance agreement regarding accident insurance, then as stated in Article 251 of the Commercial Law (from now on abbreviated as KUHD) which contains the principle of Utmost Good Faith, which emphasizes the obligation to provide information or information to the insured to provide information or correct information to the insurer. Legal consequences for the insured who do not violate Article 251 KUHD, the insurance agreement will be void and "if it cancellation of the agreement occurs based on foul reason, fraud or delinquency of the insured, then the insurer enjoys the premium, by not reducing the prosecution of public rights, if there is a reason for that "(Article 282 KUHD).

In the case of Dr. Bimanesh, if Setya Novanto entered into an insurance agreement with an insurance company, the agreement would be null and void and the premium would be given to the insurance company (this process does not need to go through the court, unless there is a dispute in the implementation of this process). 
Violations of the medical profession ethics can give legal consequences to the perpetrators. Violations of medical professional ethics need to be addressed with appropriate sanctions. In principle, giving these sanctions is also given by fellow human beings so that in granting these sanctions some individuals or institutions have more dominant power than the perpetrators. The more powerful parties will determine the complaints process, the inspection process, and the severity of the sanctions. Reference to determining the severity of sanctions is based on the loss or burden experienced by the victim. ${ }^{25}$ Provision of sanctions to violators in the medical field, the process will be submitted to MKDKI or MKEK IDI or through legal channels, namely the court.

Based on the organizational guidelines and work procedures of the MKEK IDI regulates, if MKDKI and MKDKI-P (province) has not been established, then any violations committed by doctors can be examined at MKEK IDI in each province in Indonesia. The work of MKEK IDI which explains MKEK is the only medical ethics enforcement agency since the establishment of IDI. MKEK in its historical role also expanded as a medical discipline enforcement agency which is now held by MKDKI. ${ }^{26}$

The Honorary Ethics Council of Medicine (MKEK) is one of the autonomous bodies of the Indonesian Doctors Association (IDI) which is formed specifically at the Central, Regional and Branch levels to carry out the duties of professional proficiency, fostering professional ethics and / or other institutional and ad hoc tasks at their respective levels. Respectively. The task of MKDKI is to determine whether there are errors committed by doctors and dentists in the application of medical and dental disciplines, and to determine sanctions (see Article 1 paragraph 14 of the Medical Practice Law). To enforce the discipline of doctors and dentists in the implementation of medical practice, MKDKI was formed (Article 55 paragraph (1) of the Medical Practice Law). ${ }^{27}$

MKDKI checks and gives decisions on complaints relating to the discipline of doctors and dentists (Article 67 of the Medical Practice Law). The decision of MKDKI is binding on doctors, dentists, and KKI whose contents can be in the form of innocence or disciplinary sanctions. Disciplinary sanctions can be in the form of (Article 69 of the Medical Practice Law):

\footnotetext{
25) Anna Rozaliyan et al. "Prinsip Penetapan Sanksi bagi Pelanggaran Kode Etik Kedokteran". Jurnal Kode Etik Kedokteran, 2 (1), (2018), p.19.

${ }^{26}$ Ikatan Dokter Indonesia, Pedoman Organisasi dan Tatalaksana Kerja Majelis Kehormatan Etik Kedokteran, Jakarta: Pengurus Besar Ikatan Dokter Indonesia, (2008), p.3.

${ }^{27}$ Julius Pelafu, "Pelaksanaan Penegakkan Kode Etik Kedokteran". Lex Crimen, 4 (3), (2015), p.47.
} 
1. Written warning;

2. Recommendation to revoke registration certificate or practice permit; and;

3. The obligation to attend education or training in medical or dental education institutions.

Based on the description above, MKDKI is an independent institution that has the authority to conduct violation assessments, determines the presence/absence of violations and the authority to provide sanctions for doctors suspected of violations in carrying out the practice. These violations include ethical violations, professional discipline violations, and even law violations. ${ }^{28}$ Understanding of MKDKI (Indonesian Medical Discipline Honorary Assembly) itself is contained in Article 1 paragraph 14 of the Medical Practice Law which reads: MKDKI is an authorized institution to determine whether there are errors committed by doctors and dentists in the application of medical and dental disciplines, and set sanctions. ${ }^{29}$

Along with the times, MKDKI no longer handles the problem of violations of the medical ethics code. The government then handed over the authority for the formulation, supervision, and enforcement of a code of ethics to IDI. From there IDI formed a special assembly to formulate, supervise, and enforce medical ethics in Indonesia. This institution is against perpetrators of violations of the code of ethics; sanctions will be given for their actions determination of whether a person is proven to violate the medical ethics code. One of the results of MKEK IDI's work that we can see is the creation of a medical code of ethics or KODEKI. ${ }^{30}$ Also, relating to the enforcement of the medical code of ethics, the violators will be examined and sanctioned if proven guilty, by the MKEK Organization and Procedure Guidelines (ORTALA). Based on ORTALA MKEK, giving sanctions to convicted doctors / ethical violators can be in the form of counseling, verbal warnings, written warnings, behavioral guidance, re-schooling, until the dismissal of IDI membership, either temporarily or permanently. In general, these ethical sanctions are coaching, except for the permanent dismissal of membership or revocation of a lifetime membership. The mechanism for imposing sanctions by MKEK begins with the entry of a legitimate complaint, followed by a review of the complaint case. At the end of the review, the Chair of the MKEK determined the feasibility of the case be tried by the examining council that would conduct the court session until the decision of MKEK was reached. If there is evidence that there is evidence of an ethical violation, then the panel will determine sanctions by the severity of the error of the doctor. The

\footnotetext{
28) Sapta Aprilianto, "Peran Majelis Kehormatan Disiplin Kedokteran Indonesia (MKDKI) terhadap Dugaan Kelalaian Medis Dokter", Yuridika, 30 (3), (2015), p.532.

${ }^{29)}$ Sandy Vatar Simanjuntak, "Pertanggungjawaban Pidana Oleh Dokter Yang Melakukan Tindakan Malpraktek", University of Pasundan Thesis, (2015), p.5.

30) Ibid., p 536.
} 
implementation of sanctions was carried out by the MKEK Professional Ethics Development Division for and on behalf of the IDI management level. ${ }^{31}$ The Ethics Ethics Council (MKEK) hears ethical violations and can hear violations of the medical profession discipline in areas where there is no Indonesian Disciplinary Honorary Council (MKDI). ${ }^{32}$ Ethics and professional disciplinary proceedings are carried out separately from the proceedings of civil lawsuits or criminal charges because the domain and jurisdiction are different. Doctors are suspected of violating professional standards (cases of medical negligence) can be examined by MKEK, can also be examined in court without the necessity of interconnection between the two. So, from the above explanation, we can know that MKEK must uphold medical profession ethics, while MKDKI has the task of determining whether there is a mistake in applying medical disciplines and imposing sanctions on it.

As explained at the beginning of the section, based on Article 66 paragraph 3 of the Law on Medical Practices, the existence of complaints made to MDKI or MKEK does not eliminate the right of everyone to report suspected criminal acts to the authorities and sue for civil losses to the court. This means that even if the complaint has been filed with MKDKI or MKEK IDI, the parties who feel aggrieved can still file a civil claim to court in accordance with their jurisdiction and if the violation of the code of ethics also includes a violation of criminal provisions, then the violator of the medical code of ethics It can also be submitted to parties authorized to handle criminal cases.

Based on the explanation above, Dr.Bimanesh's actions should be taken to DKI MKEK for review, and if proven to violate KODEKI, he will be given sanctions by DKI MKEK which will be adjusted according to the weight or severity of the violations he made based on the judges' consideration in the MKEK trial that. Besides that, Dr. Bimanesh can also be sentenced for violating Article 267 paragraph 1 and article 56 of the Criminal Code. Then in civil terms, Dr. Bimanesh violated Article 1365 of the Indonesian Criminal Code, which is illegal. Dr. Bimanesh will also bear such things if he is proven guilty of manipulating so that Setya Novanto is treated at Medika Permata Hijau Hospital.

\section{Conclusion}

31) Purwadianto A, Pedoman organisasi dan tata laksana kerja Majelis Kehormatan Etik Kedokteran, Jakarta: Majelis Kehormatan Etika Kedokteran Ikatan Dokter Indonesia, (2008), p.20.

32) Asep Sukohar dan Novita Carolia, "Peran Majelis Kehormatan Etik Kedokteran Indonesia (MKEK) dalam Pencegahan dan Penyelesaian Malpraktek Kedokteran", Juke Jurnal Kedokteran, 1 (2), (2016), p.368. 
The analysis above shows that Dr.Bimanesh, to do his work, has violated Article 263 of the Criminal Code, namely the falsification of letters for falsifying the information contained in the doctor's certificate for his patients. Based on this, Dr.Bimanesh was properly investigated by the investigator regarding the crime and was processed legally.

Regarding the violation of the code of ethics, Dr.Bimanesh's actions against Setya Novanto did violate KODEKI Article 3 and Article 7. Therefore, DrBimaesh should have been examined and if found guilty were given appropriate sanctions by DKI MKEK whose weight would be adjusted to its weight or light violations he made based on the considerations of the judges in the MKEK session. Civilly Dr. Bimanesh also violated Article 1365 of the Criminal Code, which is about unlawful acts. Dr. Bimanesh is late in doing things that are contrary to the law. The hospital can sue Dr. Bimanesh because it hurts his patients and Dr. Bimanesh can get a compensation claim.

\section{Suggestion}

Doctors must hold in high esteem code of ethics and oath of the profession to work independently and objectively without explicit intervention from the outside. Doctors should be the ones who help taking care of patients instead of being the ones who are guilty, punished, or sentenced. IDI mustn't hesitate to discipline doctors who aren't by the code of ethics for doctors so that doctors in Indonesia will have a professional responsibility. The community also has a role in enforcing law and orders from a very simple way, which is to stop buying fake documents since it also against the law or code of ethics for doctors because they must be honest and not misleading when writing reports and certificates, and only signing documents they believe to be accurate. 


\section{Bibliography}

\section{A. Books}

A, Purwadianto. (2008). Pedoman organisasi dan tata laksana kerja Majelis

Kehormatan Etik Kedokteran. Jakarta: Majelis Kehormatan Etika Kedokteran Ikatan Dokter Indonesia.

Chrisdiono M, Achadiat. (2004). Dinamika Etika dan Hukum Kedokteran Dalam Tantangan Zaman. Jakarta: EGC

Darwin, Eryati dan Hardisman. (2012). Etika Profesi Kesehatan. Yogyakarta: Deepublish

Hanafiah, M. Jusuf dan Amir. (2007). Etika Kedokteran dan Hukum Kesehatan. Jakarta: EGC

Hariyani, Safitri. Sengketa Medik: Alternatif penyelesaian Perselisihan antara Dokter dengan Pasien.

Ikatan Dokter Indonesia. (2008). Pedoman Organisasi Dan Tatalaksana Kerja Majelis Kehormatan Etik Kedokteran. Jakarta: Pengurus Besar Ikatan Dokter Indonesia

Isfandyarie, Anny. (2006). Tanggungjawab Hukum dan Sanksi Bagi Dokter. Jakarta: Prestasi Pustaka.

Isfandyarie, Anny. (2011). Tanggung Jawab Hukum dan Sanksi bagi Dokter. Jakarta: Prestasi Pustaka.

Marianti, Ninik. (1988). Malpraktik Kedokteran dari Segi Hukum Pidana dan Perdata. Jakarta: Bina Aksara.

Mertokusumo, Sudikno. (2005). Mengenal Hukum. Yogyakarta: Liberty.

Notoatmodjo, Soedikno. (2015). Metodologi Penelitian Kesehatan. Jakarta: Rineka Cipta

Purwadianto A. (2008). Pedoman organisasi dan tata laksana kerja Majelis Kehormatan Etik Kedokteran. Jakarta: Pengurus Besar Ikatan Dokter Indonesia

Soetrisno. (2010). Malpraktek Medik Dan Mediasi Sebagai Alternatif Penyelesaian Sengketa. Tangerang: Telaga Ilmu Indonesia

\section{B. Articles and Journal}

Asep Sukohar dan Novita Carolia, "Peran Majelis Kehormatan Etik Kedokteran Indonesia (MKEK) dalam Pencegahan dan Penyelesaian Malpraktek Kedokteran", Juke Jurnal Kedokteran, 1 (2), (2016).

Anna Rozaliyan et al. "Prinsip Penetapan Sanksi bagi Pelanggaran Kode Etik Kedokteran". Jurnal Kode Etik Kedokteran, 2 (1), (2018), https://doi.org/10.26880/jeki.v2i1.11 
Haryanto Njoto, "Pertanggungjawaban Dokter dan Rumah Sakit Akibat Tindakan Medis yang Merugikan Dalam Perspektif UU No. 44 Tahun 2009 tentang Rumah Sakit”. DiH Jurnal Ilmu Hukum, 7 (14), (2011).

Julius Pelafu, "Pelaksanaan Penegakkan Kode Etik Kedokteran". Lex Crimen, 4 (3), (2015).

Juwita Suma, "Tanggung Jawab Hukum Dan Etika Kesehatan", Jurnal Legalitas, 2 (3), (2009).

Sandy Vatar Simanjuntak, "Pertanggungjawaban Pidana Oleh Dokter Yang Melakukan Tindakan Malpraktek", University of Pasundan Thesis, (2015).

Sapta Aprilianto, "Peran Majelis Kehormatan Disiplin Kedokteran Indonesia (MKDKI) terhadap Dugaan Kelalaian Medis Dokter", Yuridika, 30 (3), (2015).

\section{Legislation}

Indonesia. Kitab Undang-Undang Hukum Pidana

Indonesia. Kitab Undang-Undang Hukum Perdata [Burgerlijk Wetboek]. Diterjemahkan oleh Subekti dan R. Tjitrosudibio.

Indonesia. Undang-Undang Nomor 29 Tahun 2004 tentang Praktik Kedokteran (Lembaran Negara Tahun 2004 Nomor 116, Tambahan Lembaran Negara Nomor 4431).

\section{World Wide Web}

Ari Nursanti. "Ini Kronologi Dugaan Persengkongkolan Dokter dan Mantan Pengacara Setya Novanto". http://www.pikiranrakyat.com/nasional/2018/01/10/ini-kronologi-dugaan-persekongkolandokter-dan-mantan-pengacara-setya-novanto, diakses pada tanggal 29 Agustus 2018 pukul 13.45. 